\title{
METHODOLOGICAL APPROACH TO EVALUATING THE POTENTIAL OF UNDER-SERVED MARKETS WITHIN THE FRAMEWORK OF CANADA-UKRAINE FREE TRADE AGREEMENT
}

UDC 339.5

(c) 2019 SERPUKHOV M. YU.

JEL Classification: D41

\author{
Serpukhov M. Yu. \\ Methodological Approach to Evaluating the Potential of Under-Served Markets within the Framework \\ of Canada-Ukraine Free Trade Agreement
}

The article analyzes the state of mutual trade between Ukraine and Canada before and after their entering into Canada-Ukraine Free Trade Agreement. The results of the operation of the free trade zone between Ukraine and Canada in terms of commodity groups and trade relations between the countries are analyzed. A study of the import structure of Canada and the export opportunities of Ukraine is carried out. Using statistical data, the results of testing a methodological approach to evaluating the potential of under-served markets within the framework of the Free Trade Agreement are presented. A methodological approach that allows to assess different aspects of the impact of free trade on the country's export activity is proposed and commodity items that have a potential for growth in the bilateral trade are determined. Conclusions on the intensification of trade between the countries are drawn; proposals for improving the export structure of Ukraine are presented; commodity groups due to which Ukrainian producers can increase a potential for export growth are identified.

Keywords: under-served markets, potential sales markets, exports, import substitution, trade barriers, protectionism, international trade, free trade agreement.

DOI: https://doi.org/10.32983/2222-0712-2019-3-5-10

Fig.: 3. Tabl.: 4. Bibl.: 9.

Serpukhov Maksym Yu. - Candidate of Sciences (Economics), Associate Professor of the Department of International Economics and Management FEA, Simon Kuznets Kharkiv National University of Economics (9a Nauky Ave., Kharkiv, 61166, Ukraine)

E-mail: maximserpuhov@gmail.com

Серпухов М. Ю. Методичний підхід до визначення потенціалу недоторгованих ринків у рамках дії Угоди про вільну торгівлю між Україною та Канадою

У статті проаналізовано стан взаємної торгівлі між Україною та Канадою до і після укладання угоди про зону вільної торгівлі між країнами. Проаналізовано результати дії зони вільної торгівлі між Україною та Канадою за товарними групами і аналізом торговельних зв'язків країн. Проведено дослідження імпортної структури Канади та експортних можливостей України. На статистичних даних представлено результати апробації методичного підходу з визначення потенціалу недоторгованих ринків у рамках дії угоди про зовнішню торгівлю. Запропоновано методичний підхід, що оцінює різні сторони впливу зони вільної торгівлі на експортну діяльність країни та дозволяє визначити торговельні позиції, які мають потенціал зростання у двосторонній торгівлі. Зроблено висновки відносно активізації торгівлі мін країнами та надано пропозиції з покращення структури експорту України, а також визначено торговельні групи, за якими українські виробники мають потенціал зростання експорту.

Ключові слова: недоторговані ринки, потенційні ринки збуту, експорт, імпортозаміщення, торговельні бар'єри, протекціонізм, міжнародна торгівля, угода про вільну торгівлю.

Рис.: 3. Табл.: 4. Бібл.: 9.

Серпухов Максим Юрійович - кандидат економічних наук, доцент кафедри міжнародної економіки та менеджменту ЗЕД, Харківський начіональний економічний університет ім. С. Кузнеця (просп. Науки, 9а, Харків, 61166, Україна)

E-mail: maximserpuhov@gmail.com
Серпухов М. Ю. Методический подход к определению потенциала недоторгованных рынков в рамках действия Соглашения о свободной торговле между Украиной и Канадой

В статье проанализировано состояние взаимной торговли между Украиной и Канадой до и после заключения соглашения о зоне свободной торговли между странами. Проанализированы результаты работы зоны свободной торговли между Украиной и Канадой по товарным группам и анализу торговых связей стран. Проведено исследование импортной структуры Канады и экспортных возможностей Украины. С использованием статистических данных представлены результаты апробации методического подхода по определению потенциала недоторгованных рынков в рамках действия соглашения о свободной торговле. Предложен методический подход, оценивающий различные стороны влияния свободной торговли на экспортную деятельность страны и позволяющий определить торговые позиции, имеющие потенциал роста в двусторонней торговле. Сделаны выводы относительно активизации торговли между странами и представлены предложения по улучшению структуры экспорта Украины, а также определены торговые группы, по которым украинские производители имеют потенциал роста экспорта.

Ключевые слова: недоторгованные рынки, потенциальные рынки сбыта, экспорт, импортозамещение, торговые барьеры, протекционизм, международная торговля, соглашение о свободной торговле.

Рис.: 3. Табл.: 4. Библ.: 9.

Серпухов Максим Юрьевич - кандидат экономических наук, доцент кафедры международной экономики и менеджмента ВЭД, Харьковский национальный экономический университет им. С. Кузнеца (просп. Науки, 9а, Харьков, 61166, Украина)

E-mail: maximserpuhov@gmail.com 
Under the conditions of intensification of integration processes in the world economy, competition among manufacturers gains a new meaning and takes new forms. On the one hand, integration processes facilitate manufacturers' easier access to external markets; on the other hand, they intensify competition in home markets due to liberalization of foreign competitors' access to these markets. The key issue to be solved in regard to this process is evaluating the potential of under-served markets of Ukraine's trade partners, who enter into a trade agreement with the country and facilitate access of Ukrainian manufacturers to their markets, as well as intensifying export activities of Ukraine in these markets [9].

Ukraine is gradually liberalizing its foreign trade activity. It has entered into a number of free trade agreements, including the Deep and Comprehensive Free Trade Area (DCFTA), which is part of the Association Agreement between the EU and Ukraine [1], and Canada-Ukraine Free Trade Agreement [2]. The free trade zone with Canada opens access to $98 \%$ of the Canadian commodity market Ukrainian exporters. The Agreement envisages the abolition of duties on import of certain agricultural products (except for 108 tariff lines, access to which is granted within quotas) as well as all industrial goods (except for light motor vehicles, with the 7-year transition period of abolition of the tariffs). Ukrainian exporters can supply commodities included in the above-mentioned 108 agricultural product tariff lines at a zero rate within the Canadian global quotas.

However, the issue of estimating the practical effect of the Canada-Ukraine Free Trade Agreement and, regarding this, evaluating the potential of under-served Canadian markets, remains understudied.

The aim of the research is assessing the changes that have occurred since the Canada-Ukraine Free Trade Agreement was signed, and, based on the research findings, to evaluate the potential of the under-served markets. The evaluation of the potential of the under-served markets of Canada will provide for focusing Ukrainian exporters' efforts on the Canadian market, which has an easier access as opposed to the markets where they face fierce competition or which they are not able to enter.

Theoretical findings of the investigation into the issues related to free trade zones functioning are presented in works of foreign and Ukrainian scientists and, among the most recent ones, researches of the following economists are worth noting:
Alan V. Deardorff, Quy-Toan Do and A. A. Levchenko considered the issue of trade policies, identification of vulnerable industries in the framework of formation of trade agreements [3].

E. D. Mansfield studied the problem of institutional barriers through the prism of concluding preferential trade agreements among individual countries, which, on the one hand, contributes to revitalization of trade among the countries participating in the agreement, and, on the other hand, creates barriers to trade with other countries [4].

L. O. Shvorak carried out research on the structure of Ukraine-Canada trade and trends in the trading relations between the two countries, and, based on the findings of his statistical study, made a conclusion on the possibilities provided by this trade agreement [5].

A. Baležentis, O. Yatsenko conducted a research into the content of trade agreements and evaluated their strengths and threats as well as made a forecast of further trends in the development of foreign trade between the countries signatories to a trade liberalization agreement [6].

The methodological approach of the research is based on evaluating the potential of the under-served markets and involves a successive analysis of the following blocks (Fig.1).

Estimation of mutual trade between the countries. The changes following the entry into force of Canada-Ukraine Free Trade Agreement are studied using the methods of comparison and statistical evaluation. Figure 2 shows the trends in the exports of Canada and Ukraine before and after their signing the Free Trade Agreement.

As seen from Figure 2, Canada and Ukraine demonstrate a gradual increase in the exports of goods after entering into the free trade agreement. The upward trend is partly owing to the effect of the Free Trade Agreement.

With regard to the fact that Ukraine and Canada have considerably different trade volumes, more specifically, Canada's export volumes exceed those of Ukraine tenfold and its foreign trade structure is more diversified, the intensification of the countries' export activity is a positive effect of the liberalization of their internal markets.

In order to determine the impact of the Free Trade Agreement on the export activity of Ukraine and Canada, it is necessary to assess trends in the exports of both countries participating in the Agreement (Fig. 3).

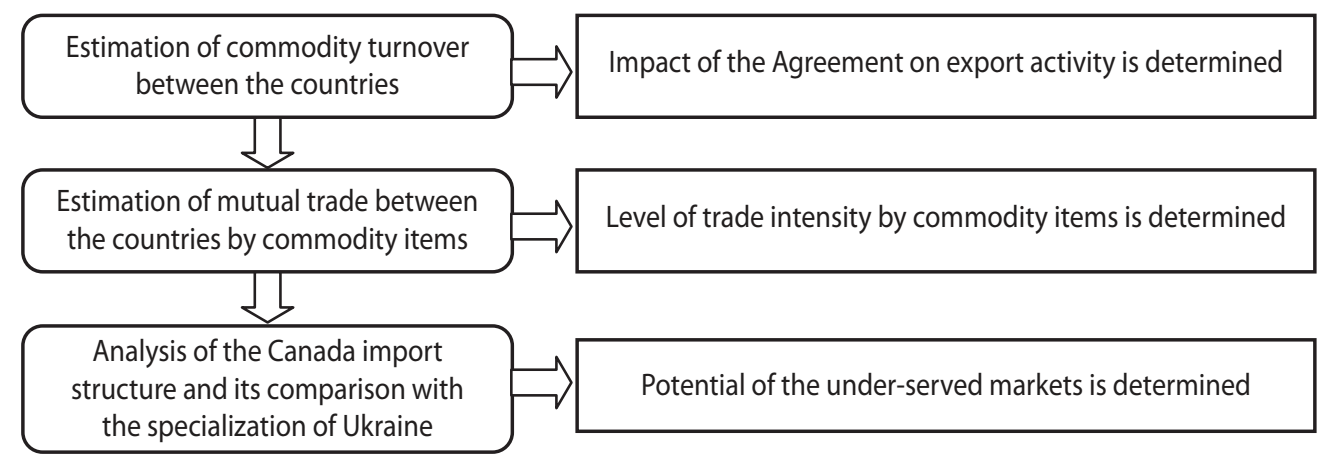

Fig. 1. Scheme of studying the potential of the under-served markets within the framework of Canada-Ukraine Free Trade Agreement

Source: developed by the author 


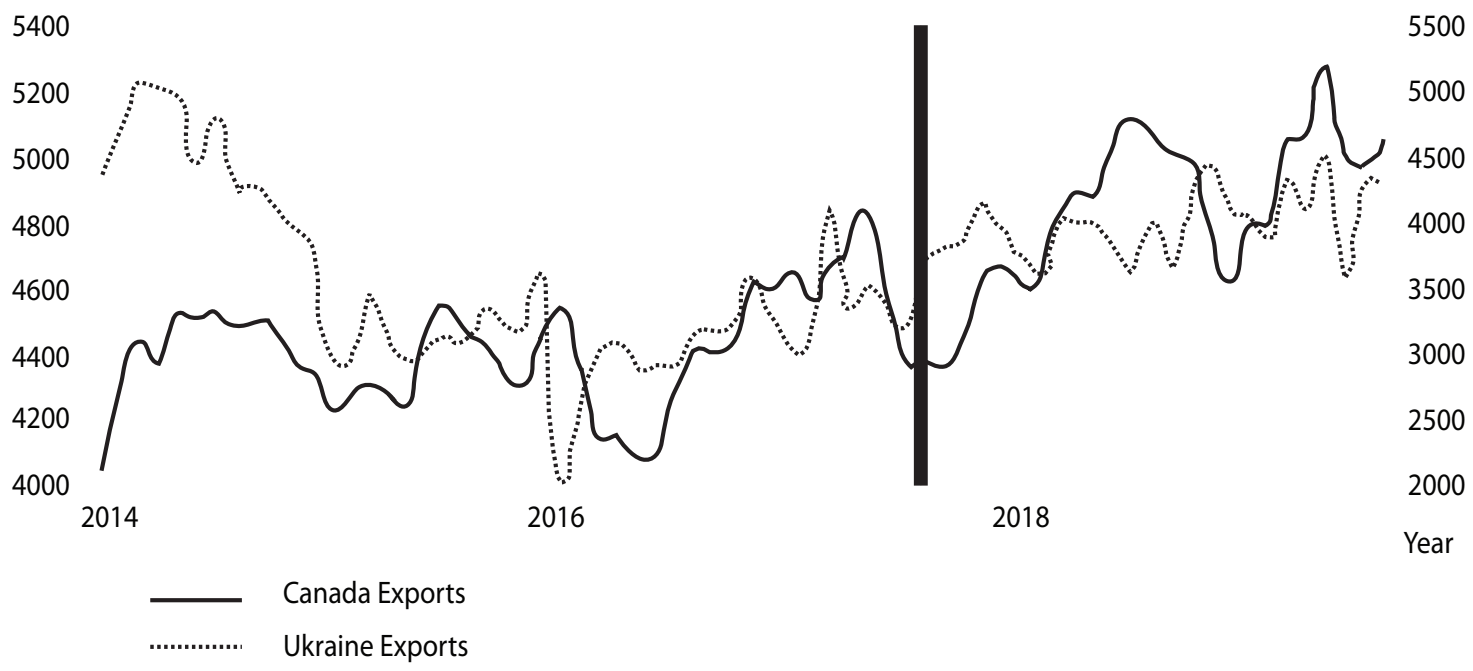

Fig. 2. Trends in Ukraine and Canada Commodity Exports, 2014-2019 (up to September 2019)

Source: developed by the author based on [7]

As can be seen, in 2016, before entering into the Free Trade Agreement, Canada had a considerable advantage over Ukraine in export volumes, i.e., it exported much more products to Ukraine than imported from it. In 2017, the Free Trade Agreement came into effect; however, the analysis of the trends in exports of the countries-participants to the Free Trade Agreement shows that Canadian exports started declining rapidly in contrast to the increasing Ukrainian exports.

It is incorrect to state that the abovementioned results were obtained only due to the Agreement since, except for liberalization of trade relations, a number of other factors impact exports, namely: trade structure, specialization, seasonality, market conjuncture, etc.

As regards trade partners and geographical trading patterns of Canada and Ukraine, it is worth analyzing the countries' positions in terms of export volume.

Trade partnership. In 2018, among trade partners of Ukraine, Canada took the $64^{\text {th }}$ place in terms of export volumes, with the volume of Ukraine's export of USD78.14 mln; while Ukraine ranked the $62^{\text {nd }}$ among trade partners of Canada with the volume of Canada's export to Ukraine of USD169.8 $\mathrm{mln}$, i.e., Ukraine has a negative trade balance of USD91.66 mln. Thus, Canada has considerable advantages in terms of trade with Ukraine, which brings to the fore the issues of the intensification of export activity and a more effective use of opportunities provided by the Free Trade Agreement.

The findings of the research into the geographical pattern of exports between Canada and Ukraine are given in Table 1.

As can be seen, the considerable geographical distance between the countries and their different specialization explain why the lists of their trade partners mostly do not coincide, except for the markets of the countries included in the category of the largest world markets.

The next stage of the methodological approach is the estimation of mutual trade between the countries by commodity items. The evaluation of the effect of the Free Trade Agreement requires analyzing the changes that have occurred in CanadaUkraine trade.

It is worthwhile studying the structure of Ukraine's exports to Canada in order to evaluate the commodity structure of exports. The results of the analysis are presented in Table 2.

As can be seen, the structure of exports of the Ukrainian commodities to the Canadian market has only 2 product lines with a relatively large export volume, which are iron and steel,

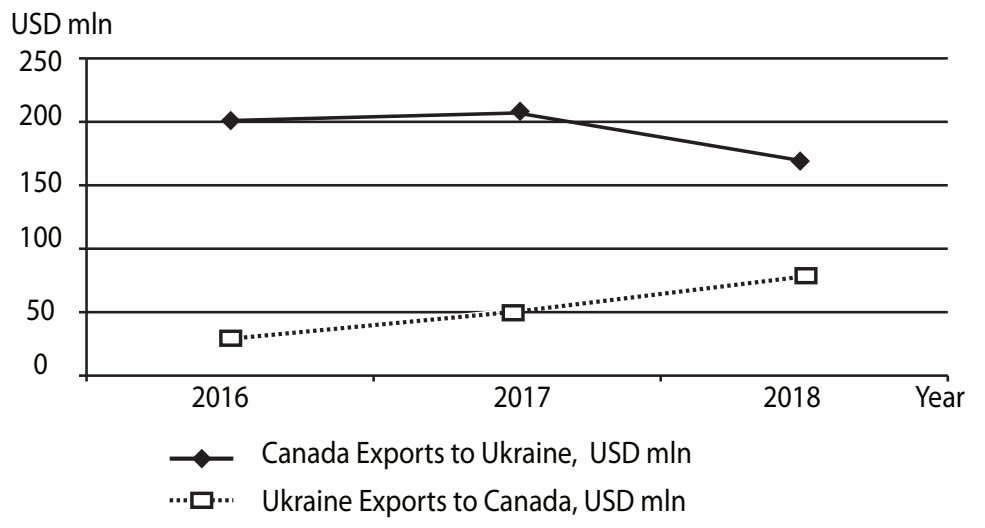

Fig. 3. Export performance in the mutual trade between Canada and Ukraine, 2016-2018

Source: developed by the author based on [7-8] 
Main Trade Partners of Ukraine and Canada by Export Category, 2018

\begin{tabular}{|c|l|c|c|l|c|}
\hline \multicolumn{3}{|c|}{ Canada Exports By Country, USD } & \multicolumn{3}{c|}{ Ukraine Exports By Country, USD } \\
\hline № & Value & export & № & Value & export \\
\hline 1 & United States & $337.81 \mathrm{~B}$ & 1 & Russia & $3.65 \mathrm{~B}$ \\
\hline 2 & China & $21.34 \mathrm{~B}$ & 2 & Poland & $3.26 \mathrm{~B}$ \\
\hline 3 & United Kingdom & $12.61 \mathrm{~B}$ & 3 & Italy & $2.63 \mathrm{~B}$ \\
\hline 4 & Japan & $10.00 \mathrm{~B}$ & 4 & Turkey & $2.35 \mathrm{~B}$ \\
\hline 5 & Mexico & $6.35 \mathrm{~B}$ & 5 & Germany & $2.21 \mathrm{~B}$ \\
\hline 6 & South Korea & $4.53 \mathrm{~B}$ & 6 & China & $2.20 \mathrm{~B}$ \\
\hline 7 & Netherlands & $3.66 \mathrm{~B}$ & 7 & India & $2.18 \mathrm{~B}$ \\
\hline 8 & Germany & $3.63 \mathrm{~B}$ & 8 & Hungary & $1.65 \mathrm{~B}$ \\
\hline 9 & India & $3.31 \mathrm{~B}$ & 9 & Netherlands & $1.60 \mathrm{~B}$ \\
\hline 10 & Hong Kong & $3.01 \mathrm{~B}$ & 10 & Egypt & $1.56 \mathrm{~B}$ \\
\hline 62 & Ukraine & $169.80 \mathrm{M}$ & 64 & Canada & $78.14 \mathrm{M}$ \\
\hline
\end{tabular}

Table 2 and copper. These goods are classified as raw materials and

Ukraine exports to Canada, 2018

\begin{tabular}{|l|c|}
\hline \multicolumn{1}{|c|}{ Products } & Value \\
\hline Iron and steel & $\$ 21.47 \mathrm{M}$ \\
\hline Copper & $\$ 14.54 \mathrm{M}$ \\
\hline $\begin{array}{l}\text { Tanning, dyeing extracts, tannins, } \\
\text { derivatives, pigments }\end{array}$ & $\$ 7.77 \mathrm{M}$ \\
\hline Vegetable, fruit, nut food preparations & $\$ 5.98 \mathrm{M}$ \\
\hline Machinery, nuclear reactors, boilers & $\$ 5.90 \mathrm{M}$ \\
\hline Vehicles other than railway, tramway & $\$ 4.82 \mathrm{M}$ \\
\hline Articles of iron or steel & $\$ 2.46 \mathrm{M}$ \\
\hline Wood and articles of wood, wood charcoal & $\$ 1.93 \mathrm{M}$ \\
\hline Toys, games, sports requisites & $\$ 1.51 \mathrm{M}$ \\
\hline $\begin{array}{l}\text { Animal, vegetable fats and oils, cleavage } \\
\text { products }\end{array}$ & $\$ 1.37 \mathrm{M}$ \\
\hline $\begin{array}{l}\text { Furniture, lighting signs, prefabricated } \\
\text { buildings }\end{array}$ & $\$ 1.08 \mathrm{M}$ \\
\hline Ships, boats, and other floating structures & $\$ 1.03 \mathrm{M}$ \\
\hline Ceramic products & $\$ 809.00 \mathrm{~K}$ \\
\hline Articles of apparel, knit or crocheted & $\$ 676.01 \mathrm{~K}$ \\
\hline Glass and glassware & $\$ 670.06 \mathrm{~K}$ \\
\hline Beverages, spirits and vinegar & $\$ 501.41 \mathrm{~K}$ \\
\hline Mineral fuels, oils, distillation products & $\$ 421.15 \mathrm{~K}$ \\
\hline Optical, photo, technical, medical apparatus & $\$ 416.78 \mathrm{~K}$ \\
\hline Miscellaneous chemical products & $\$ 407.50 \mathrm{~K}$ \\
\hline $\begin{array}{l}\text { Cereal, flour, starch, milk preparations and } \\
\text { products }\end{array}$ & $\$ 398.94 \mathrm{~K}$ \\
\hline Cocoa and cocoa preparations & $\$ 329.50 \mathrm{~K}$ \\
\hline $\begin{array}{l}\text { Milling products, malt, starches, inlin, wheat } \\
\text { gluten }\end{array}$ & $\$ 319.34 \mathrm{~K}$ \\
\hline Miscellaneous edible preparations & $\$ 281.37 \mathrm{~K}$ \\
\hline Plastics & $\$ 257.24 \mathrm{~K}$ \\
\hline
\end{tabular}
significantly exceed other commodity groups in their volumes. In general, the structure of Ukraine exports to the Canadian market is characterized by a low-level diversification of commodity groups and small export volumes. The majority of commodity groups in Ukraine exports present raw materials and semi-finished goods with a low added value. The analysis of the structure of Canadian exports to the Ukrainian market is given in Table 3.

Table 3

Canada exports to Ukraine, 2018

\begin{tabular}{|l|c|}
\hline \multicolumn{1}{|c|}{ Products } & Value \\
\hline \multicolumn{1}{|c|}{$\mathbf{1}$} & $\mathbf{2}$ \\
\hline Mineral fuels, oils, distillation products & $\$ 67.39 \mathrm{M}$ \\
\hline Fish, crustaceans, molluscs, aquatics invertebrates & $\$ 39.55 \mathrm{M}$ \\
\hline Machinery, nuclear reactors, boilers & $\$ 15.35 \mathrm{M}$ \\
\hline Pharmaceutical products & $\$ 10.74 \mathrm{M}$ \\
\hline Vehicles other than railway, tramway & $\$ 7.72 \mathrm{M}$ \\
\hline Commodities not specified according to kind & $\$ 5.85 \mathrm{M}$ \\
\hline Residues, wastes of food industry, animal fodder & $\$ 4.25 \mathrm{M}$ \\
\hline Electrical, electronic equipment & $\$ 2.70 \mathrm{M}$ \\
\hline Meat and edible meat offal & $\$ 2.27 \mathrm{M}$ \\
\hline Optical, photo, technical, medical apparatus & $\$ 2.04 \mathrm{M}$ \\
\hline Aircraft, spacecraft & $\$ 1.88 \mathrm{M}$ \\
\hline Oil seed, oleagic fruits, grain, seed, fruits & $\$ 1.56 \mathrm{M}$ \\
\hline Products of animal origin & $\$ 1.27 \mathrm{M}$ \\
\hline Essential oils, perfumes, cosmetics, toileteries & $\$ 1.14 \mathrm{M}$ \\
\hline Articles of iron or steel & $\$ 797.20 \mathrm{~K}$ \\
\hline Plastics & $\$ 792.02 \mathrm{~K}$ \\
\hline Arms and ammunition, parts and accessories & $\$ 490.7 \mathrm{~K}$ \\
\hline Aluminum & $\$ 478.75 \mathrm{~K}$ \\
\hline
\end{tabular}


End tbl. 3

\begin{tabular}{|l|c|}
\hline \multicolumn{1}{|c|}{$\mathbf{1}$} & $\mathbf{2}$ \\
\hline Edible vegetables and certain roots and tubers & $\$ 459.23 \mathrm{~K}$ \\
\hline Edible fruits, nuts, peel of citrus fruit, melons & $\$ 453.37 \mathrm{~K}$ \\
\hline Miscellaneous edible preparations & $\$ 336.07 \mathrm{~K}$ \\
\hline Vegetable, fruit, nut food preparations & $\$ 209.72 \mathrm{~K}$ \\
\hline $\begin{array}{l}\text { Inorganic chemicals, precious metal compound, } \\
\text { isotope }\end{array}$ & $\$ 195.32 \mathrm{~K}$ \\
\hline Rubbers & $\$ 171.02 \mathrm{~K}$ \\
\hline
\end{tabular}

As seen from Table 3, Canada exports to Ukraine 6 commodity groups with a considerably larger export volumes compared to other product groups. The majority of commodity groups in Canadian exports are represented by finished products with a high added value, in contrast to the Ukrainian export.

The final block of the research covers the analysis of the structure of Canada imports and its correlation with the export specialization of Ukraine (Tbl. 4).

Table 4

Comparison of the structure of Canada imports and Ukraine exports by the corresponding commodity groups, 2018

\begin{tabular}{|l|c|c|}
\hline \multicolumn{1}{|c|}{ Product } & $\begin{array}{c}\text { Canada } \\
\text { imports, } \\
\text { USD mln. }\end{array}$ & $\begin{array}{c}\text { Ukraine } \\
\text { exports, } \\
\text { USD mln. }\end{array}$ \\
\hline \multicolumn{1}{|c|}{$\mathbf{2}$} & $\mathbf{3}$ \\
\hline Machinery, nuclear reactors, boilers & 68940 & 1720.0 \\
\hline Electrical, electronic equipment & 44900 & 2930.0 \\
\hline $\begin{array}{l}\text { Optical, photo, technical, medical } \\
\text { apparatus }\end{array}$ & 12580 & 145.6 \\
\hline Articles of iron or steel & 10810 & 1110.0 \\
\hline $\begin{array}{l}\text { Furniture, lighting signs, } \\
\text { prefabricated buildings }\end{array}$ & 9340 & 625.8 \\
\hline Pearls, precious stones, metals, coins & 8760 & 62.4 \\
\hline Aircraft, spacecraft & 8380 & 61.1 \\
\hline Iron and steel & 7940 & 9940.0 \\
\hline Organic chemicals & 6810 & 229.6 \\
\hline $\begin{array}{l}\text { Paper and paperboard, articles of } \\
\text { pulp, paper and board }\end{array}$ & 5670 & 482.3 \\
\hline Beverages, spirits and vinegar & 5060 & 229.6 \\
\hline $\begin{array}{l}\text { Edible fruits, nuts, peel of citrus fruit, } \\
\text { melons }\end{array}$ & 4790 & 228.6 \\
\hline $\begin{array}{l}\text { Articles of apparel, not knit or } \\
\text { crocheted }\end{array}$ & 4590 & 404.2 \\
\hline Aluminum & 4500 & 132.0 \\
\hline Toys, games, sports requisites & 4460 & 115.0 \\
\hline $\begin{array}{l}\text { Inorganic chemicals, precious metal } \\
\text { compound, isotope }\end{array}$ & 4400 & 883.2 \\
\hline $\begin{array}{l}\text { Edible vegetables and certain roots } \\
\text { and tubers }\end{array}$ & 3130 & 235.7 \\
\hline
\end{tabular}

End tbl. 4

\begin{tabular}{|l|c|c|}
\hline \multicolumn{1}{|c|}{$\mathbf{1}$} & $\mathbf{2}$ & $\mathbf{3}$ \\
\hline $\begin{array}{l}\text { Wood and articles of wood, wood } \\
\text { charcoal }\end{array}$ & 3080 & 1490.0 \\
\hline $\begin{array}{l}\text { Cereal, flour, starch, milk } \\
\text { preparations and products }\end{array}$ & 3040 & 268.3 \\
\hline Miscellaneous edible preparations & 2860 & 268.3 \\
\hline Glass and glassware & 2610 & 160.3 \\
\hline Miscellaneous articles of base metal & 2580 & 148.8 \\
\hline Footwear, gaiters and the like, & 2520 & 194.5 \\
\hline Copper & 2500 & 139.7 \\
\hline $\begin{array}{l}\text { Vegetable, fruit, nut food } \\
\text { preparations }\end{array}$ & 2350 & 172.3 \\
\hline $\begin{array}{l}\text { Tanning, dyeing extracts, tannins, } \\
\text { derivatives, pigments }\end{array}$ & 2340 & 101.3 \\
\hline
\end{tabular}

As can be seen from the comparing of the structure of Canada imports and Ukraine exports by the corresponding commodity groups, the biggest product categories imported by Canada and related to the Ukrainian export specialization are:

- Machinery, nuclear reactors, boilers;

- Electrical, electronic equipment;

- Optical, photo, technical, medical apparatus;

- Articles of iron or steel;

- Furniture, lighting signs, prefabricated buildings.

Canada imports a significant volume of these commodities while Ukraine provides the necessary export volumes only in three categories, which testifies that the market for these product categories is under-served.

Considering the correlation between the commodities that have the largest share in Canada imports and the structure of Ukraine exports, it can be asserted that Ukraine can cover the demand of the Canadian economy for imported goods only in three commodity groups:

- Iron and steel;

- Wood and articles of wood, wood charcoal;

- Articles of iron or steel.

As can be seen, these categories include raw materials with a low added value. However, there is a considerable potential for promoting other groups of commodities with a higher added value, which must be further developed to export these products to the Canadian market.

Therefore, having considered Canada-Ukraine Free Trade Agreement and proceeding from the application of the proposed methodological approach to the evaluation of the potential of under-served markets within the framework of Canada-Ukraine Free Trade Agreement, it is possible to conclude the following:

- the analysis of the impact of the Free Trade Agreement on the countries based on the results of its entry in force demonstrated an increase in the Ukraine export volumes and decline in the Canada export volumes;

- Canada is not the main trade partner of Ukraine as well as the Canadian market is not one of the main trade areas for Ukraine; 
- the structure of Ukraine export to Canada has a low level of diversification and is dominated by raw materials with a low added value;

- the structure of Canada exports to Ukraine is much stronger and the volumes of exported commodities is larger. Ukraine imports products with a high added value from Canada and demonstrates a negative balance of trade

Having applied the approach of comparing the structure of Canadian imports with the Ukrainian export capacity, commodity items that are in demand on the Canadian market were identified. The markets for these categories of products are characterized as "under-served markets", i.e., the ones in which Ukraine must develop its specialization and can increase its commodity exports to the Canadian market. This refers, in particular, to commodity items with a high added value.

In general, Ukraine's entering into Canada-Ukraine Free Trade Agreement has a positive effect for our country. Further efforts of Ukraine should be aimed at the intensification of its export activity and a more effective use of opportunities provided by the Free Trade Agreement.

\section{LITERATURE}

1. Угода про Поглиблену та всеохоплюючу зону вільної торгівлі (ПВЗВТ). URL: https://www.kmu.gov.ua/ua/diyalnist/ yevropejska-integraciya/ugoda-pro-asociacyu

2. Угода про вільну торгівлю між Україною та Канадою. URL: https://zakon5.rada.gov.ua/laws/show/en/124_052-16

3. Deardorff A., Quy-Toan D., Levchenko A. Trade Policy and Redistribution when Preferences are Non-Homothetic. Economics Letters. 2017. Vol. 155. P. 92-95.

4. Mansfield E. D., Pevehouse J. C. W. The expansion of preferential trading arrangements International. Studies Quarterly. 2013. Vol. 57. Issue 3. P. 592-604.

5. Шворак Л. О. Модальності участі україни у сучасних інтеграційних процесах. URL: http://journals.iir.kiev.ua/index. php/apmv/article/download/2826/2534

6. Балежентіс А., Яценко О. Асиметрії торговельної інтеграції України та ЄC. URL: http://iepjournal.com/journals/28/ 2018_2_Basenentius_Yatsenko.pdf

7. Trading economics. URL: https://tradingeconomics.com/
8. Державна служба статистики України. URL: http:// ukrst1. at.gov.ua

9. Про схвалення Експортної стратегії України («дорожньої карти» стратегічного розвитку торгівлі) на 20172021 роки. URL: https://www.kmu.gov.ua/ua/npas/pro-shvalennya-eksportnoyi-strategiyi-ukrayini-dorozhnoyi-karti-strategichnogo-rozvitku-torgivli-na-20172021-roki

\section{REFERENCES}

Balezhentis, A., and Yatsenko, O. "Asymetrii torhovelnoi intehratsii Ukrainy ta YeS" [Asymmetries of trade integration of Ukraine and the EU]. http://iepjournal.com/journals/28/2018_2_ Basenentius_Yatsenko.pdf

Deardorff, A., Quy-Toan, D., and Levchenko, A. “Trade Policy and Redistribution when Preferences are Non-Homothetic". Economics Letters, vol. 155 (2017): 92-95.

Derzhavna sluzhba statystyky Ukrainy. http://ukrstat.gov.ua

Mansfield, E. D., and Pevehouse, J. C. W. "The expansion of preferential trading arrangements International". Studies Quarterly, vol. 57, no. 3 (2013): 592-604.

"Pro skhvalennia Eksportnoi stratehii Ukrainy («dorozhnoi karty» stratehichnoho rozvytku torhivli) na 2017-2021 roky" [On approval of the Export Strategy of Ukraine (the «road map» of strategic trade development) for 2017-2021]. Derzhavna sluzhba statystyky Ukrainy. https://www.kmu.gov.ua/ua/npas/pro-shvalennyaeksportnoyi-strategiyi-ukrayini-dorozhnoyi-karti-strategichnogorozvitku-torgivli-na-20172021-roki

Shvorak, L. O. "Modalnosti uchasti Ukrainy u suchasnykh intehratsiinykh protsesakh" [Modalities of Ukraine's participation in modern integration processes]. http://journals.iir.kiev.ua/index. php/apmv/article/download/2826/2534

Tradingeconomics. https://tradingeconomics.com/

"Uhoda pro Pohlyblenu ta vseokhopliuiuchu zonu vilnoi torhivli (PVZVT)" [Agreement on the Deep and Comprehensive Free Trade Area (DCFTA)]. https://www.kmu.gov.ua/ua/diyalnist/ yevropejska-integraciya/ugoda-pro-asociacyu

"Uhoda pro vilnu torhivliu mizh Ukrainoiu ta Kanadoiu" [Free Trade Agreement between Ukraine and Canada]. https://zakon5.rada.gov.ua/laws/show/en/124_052-16

Стаття надійшла до редакції 15.08.2019 